\title{
Kurusu
}

The Price of Progress in a Japanese Village, 195 I-1975

Robert J. Smith. Returning in 1975 to a remote village he had first studied in $195 \mathrm{I}$, the author found the quality of life there drastically altered, not only by the advent of television and modern gadgets but by the decline of the religious observances, social customs, and family relationships that had once given the village a strong sense of community. Through accounts of the histories of several families, as well as a close look at virtually all aspects of village life, the author explores the circumstances that led to these far-reaching changes. $\$$ i 5.00

\section{Women in Russia}

Edited by Dorothy Atkinson, Alexander Dallin $\mathfrak{G}$ Gail Warshofsky Lapidus. Eighteen histerians and social scientists discuss various aspects of Russian women's lives from earliest times to the present, with an emphasis on their problems and opportunities in the Soviet Union today. Topics include the current status of women in industry, agriculture, and the professions; the issues of equal pay for equal work; marriage law and the family; sex stereotypes in children's textbooks; social services; and political participation. \$I8.75

\section{Famine in Tudor and Stuart England}

Andrew B. Appleby. Challenging the widely held belief that early modern England was spared subsistence crises, this study shows that the northwestern English counties of Cumberland and Westmorland suffered severe famines in 1587,1597 , and I623. Through a systematic analysis, the author shows that the deaths were not caused by epidemic diseases, as most historians have maintained, but by starvation. \$ 44.50

\section{Stanford University Press}




\section{SOCIAL RESEARCH}

AN INTERNATIONAL QUARTERLY OF THE SOCIAL SCIENCES VOLUME 45, NUMBER 1, SPRING 1978

A Publication of the Graduate Faculty New School for Social Research ON THE WORK OF MEYER SCHAPIRO

Sketch for a Portrait of the Art Historian among Artists

Six Notes in the Margin of Meyer Schapiro's Words and Pictures

THOMAS B. HESS

Semiotics and the Critical Sensibility:

Observations on the Lessons of Meyer Schapiro

Mode and Expression in Meyer Schapiro's Writings on Art

HUBERT DAMISCH

DAVID ROSAND

Schapiro, Marx, and the Reacting Sensibility of Artists

Dialectical Reasoning in Meyer Schapiro

Style in the Visual Arts as Material for Social Research

MOSCHE BARASCH

WAYNE ANDERSEN DONALD B. KUSBIT

On Rereading "Style"

DAVID H. WRIGHT

Insight and Outlook

JAMES S. ACKERMAN

On Moral Codes and Modern War JOHN PLUMMER

Political Thinking in Heidegger

ARTHUR C. DANTO REINER SCHÜRMANN

Individual Subscriptions: \$12.00; Institutions: $\$ 20.00$. Single Issues: $\$ 3.50$ ea. Editorial and Business Office: 66 West 12th Street, New York, N.Y. 10011 


\section{Victorian Imperialism}

\section{C.C. Eldridge}

The British Empire during the reign of Queen Victoria has been the subject of much recent controversy. Dr. Eldridge summarises the latest findings and presents a balanced picture of the reasons that lay behind the acquisition of colonies in many parts of the world at different times. Contrasting views, that the empire was a necessity to Britain or that the colonies were, in Disraeli's famous phrase 'a millstone round our necks', are compared, and the economic, political, social and 'emotional' factors behind colonisation are analysed and assessed.
Boards

\section{The Emergence of the Labour Party 1880-1924}

\section{Roger Moore}

The foundation of the Labour Party and its success in replacing the Liberals as the main alternative to Conservatism form the substance of the author's account of a vitally important period in modern history. Without over simplification, he describes the precise contribution of Socialist enthusiasts, middle-class intellectuals, and trade unionists to bringing the Labour Party to power. This book makes possible a clearer understanding of the Labour Party's traditions, strengths and problems in an age of political upheaval.
Boards
€7.50
0340178906
*Paperback
E3.50
0 340178914

*Teachers are invited to write for inspection copies.

Hodder \& Stoughton

Dept. E1400, P.O. Box 702, Mill Road,

Dunton Green, Sevenoaks, Kent TN13 2YD. 

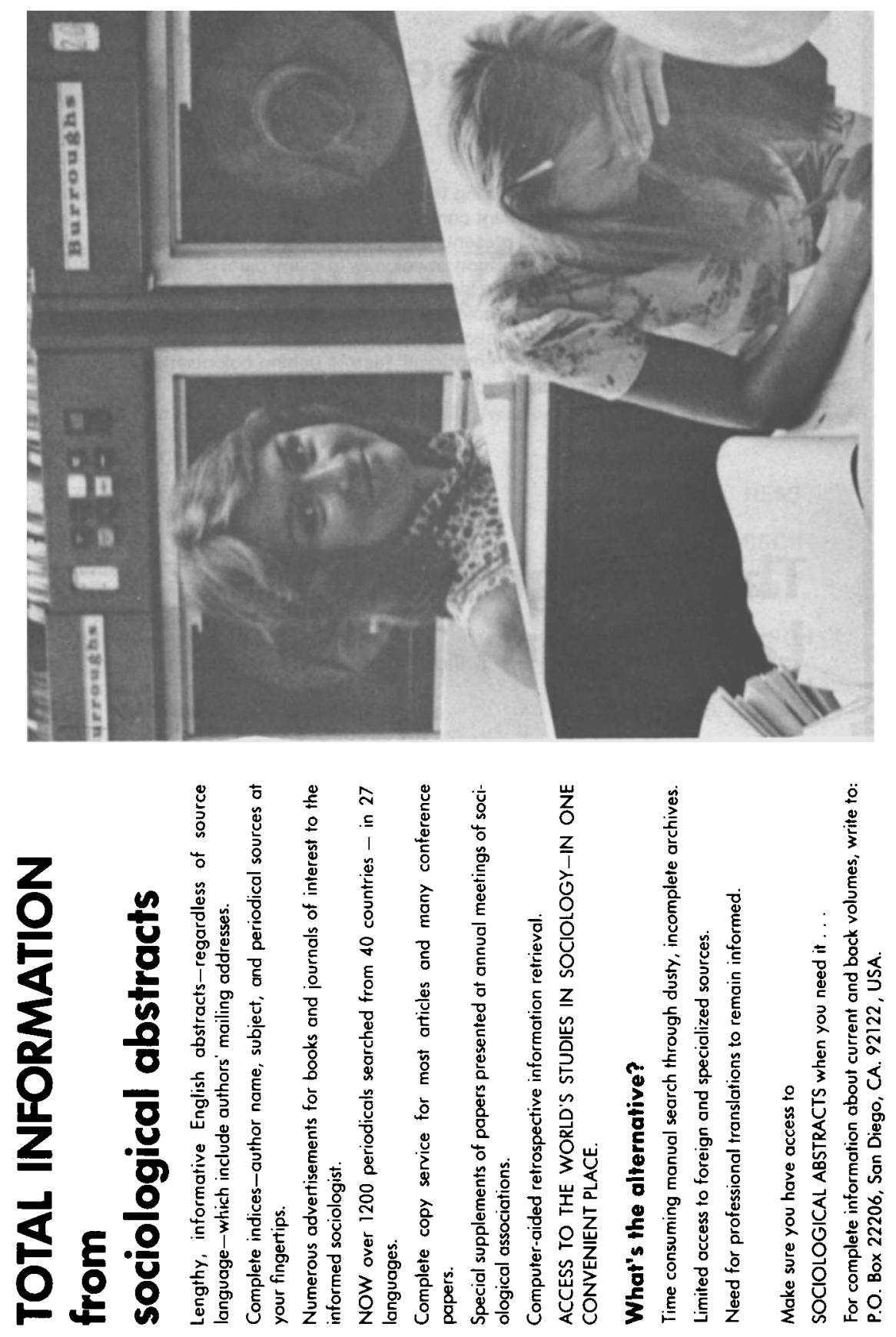


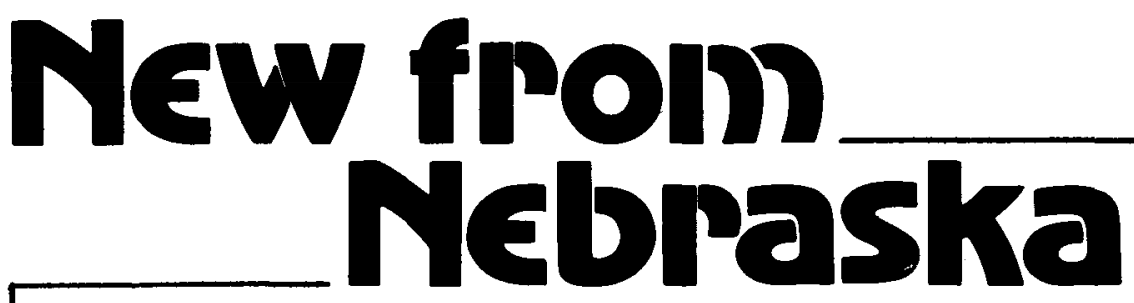

\section{THE ITALIAN NATIONALIST ASSOCIATION}

\section{AND THE RISE OF FASCISM IN ITALY}

\section{By Alexander J. De Grand}

After Mussolini himself, the Italian Nationalist Association made the single most important contribution to the construction of the Fascist system. Like the Action Française, but far more successfully, the Italian Nationalists broke with liberal parliamentary democracy to develop an aggressive response to the challenge presented by the working class and the Socialist party. Professor De Grand's study is the first full-length treatment in English of the Italian Nationalist Association and the first to make use of the Federzoni family papers.

xii, 238 pages

$\$ 12.50$

\section{THE POLITICS OF ANTIPOLITICS}

\section{The Military in Latin America}

\section{Edited by Brian Loveman and Thomas M. Davies, Jr.}

Bringing together readings on the military in Latin America from diverse Latin American and United States sources, this anthology focuses on what the editors term "antipolitics"-the rejection by the military of "politics" with its conflicts among personalist factions or political parties as justification for the establishment of long-term military rule. Selections ranging from historical studies to case studies, official U.S. documents, and speeches by military caudillos illustrate the underlying similarities between Latin American military governments and trace those similarities back to the Hispanic military tradition.

xii, 310 pages

Cloth $\$ 19.95$

Paper $(B B$ 672) $\$ 5.95$

\section{University of NEBRASKA Press 901 North 17th Street, Lincoln 68588}




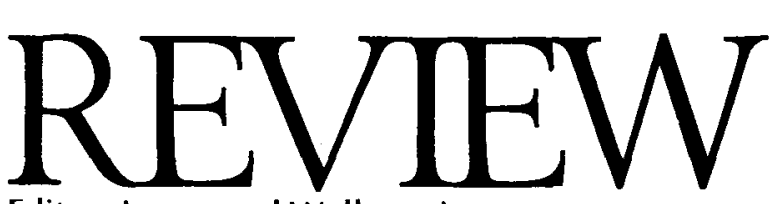

Editor: Immanuel Wallerstein a journal of the Fernand Braudel Center for the Study of Economies, Historical Systems, and Civilizations

Review is committed to the pursuit of a perspective which recognizes the primacy of analysis of economies over long historical time and large space, the holism of the socio-historical process, and the transitory (heuristic) nature of theories.

Contents of Volume I, Nos. 1 and 2, include:

Anouar Abdel-Malek

Arghiri Emmanuel

André Gunder Frank

Huri İslamoglu and Çăklar Keyder

E. Le Roy Ladurie

Karl Polanyi
East Wind

Gains and Losses from the International Division of Labor

Long Live Transideological Enterprise! The Socialist Economies in the Capitalist International Division of Labor

Agenda for Ottoman History

Occitania in Historical Perspective

The Economistic Fallacy

Double issue on "The Impact of the Annales School on the Social Sciences," Vol. 1, No. 3/4, including articles by Fernand Braudel, Jacques Revel, Traian Stoianovich, Halil Inalcik, Peter Burke, Eric J. Hobsbawm, Norman Birnbaum

I wish to subscribe to Review for one year (four issues). I enclose a check for $\$ 10$ payable to Fernand Braudel Center, State University of New York at Binghamton, Binghamton, New York 13901, U.S.A.

Name

Address

City Country Postal Code 


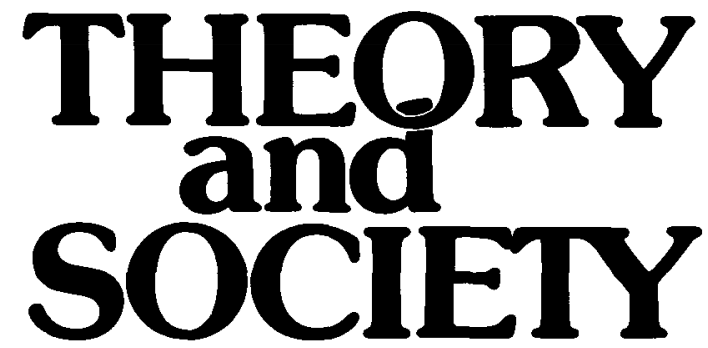

\section{RENEWAL AND CRITIQUE IN SOCIAL THEORY}

Editors: ALVIN W. GOULDNER, Editor-in-Chief, St. Louis.

ERVING GOFFMAN, Philadelphia, DEREK PHILLIPS, Amsterdam.

PAUL WALTON, London. ROD AYA, Amsterdam.

ANTHONY GIDDENS, Cambridge, U.K. JEROME KARABEL, Cambridge, U.S.A.

Special Advisory Editor: ROBERT MERTON, New York.

As it enters its fifth year of publication, THEORY and SOCIETY is expanding from a quarterly to a bi-monthly publication. At the same time, it is broadening its focus to include more work centered on an historically informed understanding of everyday life. The central concern of the journal remains, as before, social theory developed by rigorous scholarship and research. In addition, attention will be directed toward two subsidiary concerns, (1) the interface between theory and politics and (2) cultural criticism. THEORY and SOCIETY is of particular interest to, and a voice for, those new types of social scientists who are moving beyond sterile specializations and narrow "professionalism" toward wider syntheses.

\section{Appearing in 1978:}

On Transformations of Aggressiveness (Norbert Elias)

Social Class and Arts Consumption (Paul J. DiMaggio and Michael Useem)

Monarchies and Parliaments in Early Modern Europe (H. G. Koenigsberger)

Marxism and the New Middle Classes: French Critiques (George Ross)

The Social Control Thesis and Educational Reform (Erwin H. Epstein)

\section{Subscription information:}

1978 - Volumes 5,6 (in six issues)

US $\$ 63.75 / \mathrm{Dfl} 156.00$ for libraries and institutes

only US \$18.50/Df1. 45.00 for individuals

(prices include postage)

Special rates are available for

two and three year subscriptions.
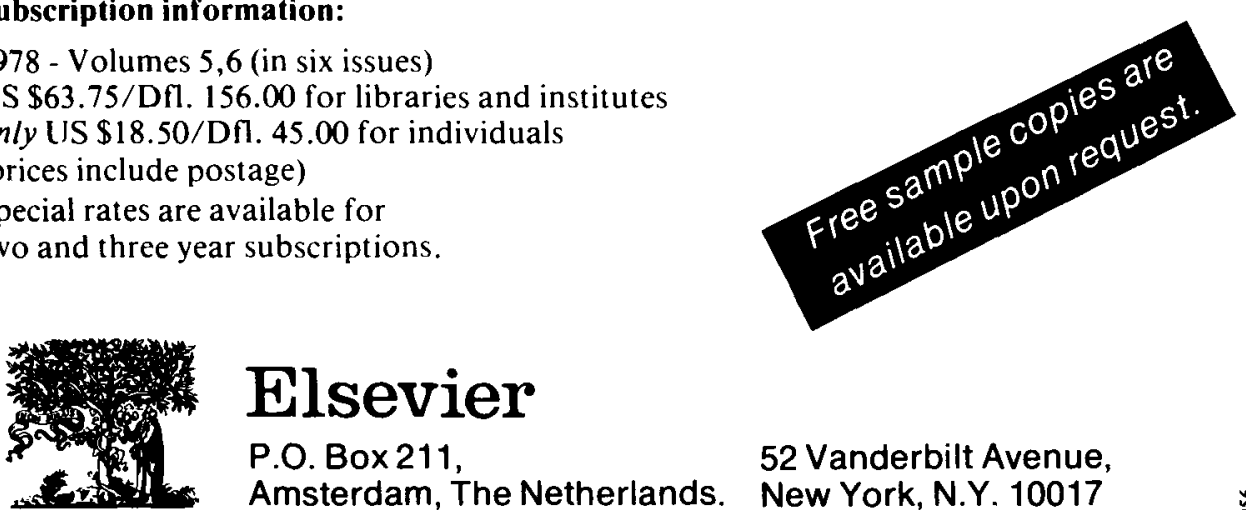


\section{Minerva}
A REVIEW OF SCIENCE, LEARNING AND POLICY
Editor: Edward Shils

VOLUME XV NUMBER 2

SUMMER 1977

\section{ARTICLES}

An Approach to the Central Planning of British Science: The Formation of the Advisory Council on Scientific Policy Philip J. Gummett and Geoffrey L. Price

Reflections on Western Technology and "Third World" Development Peter Bauer

The Distinctiveness and Universality of Science: Reflections on the Work of Professor Robin Horton Yehuda Elkana

Government and the Technological Sciences in the Soviet Union: The Rise of the Academy of Sciences Robert A. Lewis

\section{REPORTS AND DOCUMENTS}

The Soil and Air of Academic Life:

I The Shadow of Keynes Harry G. Johnson

II Academic Conviviality Marianne Weber

\section{BOOK REVIEWS}

Reviews by Arthur Steiner, Bruce L. R. Smith

Annual subscription: $£ 8.00 / \$ 18.00$

Single copy: $£ 2.50 / \$ 5.00$

MINERVA, 59 St. Martin's Lane, London WC2N 4JS 


\title{
Annual Series
}

\section{RESEARCH IN ECONOMIC ANTHROPOLOGY An Annual Compilation of Research}

\author{
Series Editor: George Dalton, Department of Economics and Anthropology, \\ Northwestern University.
}

The essays in this annual series consist of original research done by an international community of anthropologists, economists, historians, and sociologists writing on pre-industrial economies and their modern transformation, particularly in the Third World of Africa, Asia, Latin America, the Caribbean, the Middle-East, and Oceania. The principal topics to be treated are the organization and performance of tribal and peasant economies under pre-colonial, colonial, and post-colonial conditions; also, related themes in economic anthropology and early economic history, such as external trade, tribute money, ceremonial exchange, alliance networks, technology, ecology, and the economic organization of traditional kingdom-states. Papers on topics in modern rural development, such as cooperatives, land reform, settlement schemes, and agricultural innovation, will also be included.

$\begin{array}{lccc}\text { Volume } 1 . \quad \text { March } 1978 & \text { Cloth } 321 \text { pages } & \begin{array}{l}\text { Institutions } \$ 25.00 \\ \text { Individuals } \$ 12.50\end{array}\end{array}$

CONTENTS: Introduction, George Dalton. The Origins of Money, Philip Grierson, Cambridge University. Slaves, Trade and Taxes: The Material Basis of Political Power in Pre-Colonial West Africa, Robin Law, University of Stirling, Scotland. Factors of Production, Economic Circulation and Inequality in Inner Arabia, Fredrik Barth, University of Oslo. Finance and Production Revisited: In Pursuit of a Comparison, A. Strathern, University College, London. Exchange as Structure, Or Why Doesn't Everybody East His Own Pigs, Abraham Rosman and Paula G. Rubel, Barnard College, Columbia University. The Impact of Colonization on Aboriginal Economies in Stateless Societies, George Dalton, Northwestern University. The Economic Basis of Tallensi Social History in the Early Twentieth Century, Keith Hart, Yale University. The Destructive Consequences of Peasant Culture in Modern Italy, Carlo Tullio-Altan, University of Florence. Patterns of Market Expansion in the Nineteenth Century: A Quantitative Study, Irma Adelman, University of Maryland, and Cynthia Taft Morris, American University. Socialism and Economic Growth, W. Arthur Lewis, Princeton University.

Volume 2. Spring 1979 Cloth Aprox. 350 pages ISBN NUMBER 0-89232-085-0
Institutions $\$ 25.00$ Individuals $\$ 12.50$

TENTATIVE CONTENTS: Introduction: Economies and Time Periods in Economic Anthropology, George Dalton, Northwestern University. Marx and Polanyi, Yoshiro Tamanoi, University of Tokyo. The Golden Stool and the Elephant's Tail: Wealth in Asante, Ivor Wilks, Northwestern University. Goldmining and the State in the Akan Region, Ray E. Dumett, Purdue University. On the Organization of Collective Work: Inland Fishing Expeditions in Central Seram, Indonesia, Valerio Valeri, University of Chicago. Trade Among Hunters and Fishermen of Tierra Del Fuego: The Salk'nam, Haush, Yamona, and Ala Klauf, Anne Chapman, Centre National de la Recherche Scientifique, Paris. Ceremonial Exchanges in Melanesia, Paul Sillitoe, Trinity College, Cambridge. Rural Period Markets in roman North Africa as Mechanisms of Social Integration and Control. Brent Shaw, University of Lethbridge. On Land Disputes in Eastern Turkey, Nur Yalman, Harvard University. The Impact of Christianity on a Melanesian Economy, Stuart Berde, University of Massachusetts, Boston. The Struggle for Survival of a Fishing Community in Industrial Japan, Harumi Befu, Stanford University. The Effects of Reservation Bordertowns and Energy Exploitation on American Indian Economic Development, Nancy J. Owens, Northern Cheyenne Research Project. The Socio-Economics of Ranching in Kenya, lan Livingstone, University of Newcastle upon Tyne.

A 10 percent discount will be granted on all institutional standing orders placed directly with the publisher. Standing orders will be filled automatically upon publication and will continue until cancelled. Please indicate which volume Standing Order is to begin with. 


\section{THE WORLD TODAY}

The monthly journal of the Royal Institute of International Affairs provides the general reader with up-to-date authoritative information on current world problems.

Recent issues include:

Paul Wilkinson

Philip Windsor

Martin Nicholson

Sir Cyril Pickard

Geoffrey Goodwin

Anthony Delius
Terrorism: the international response

A watershed for Nato

The new Soviet Constitution: a political analysis

Change in Pakistan

The Unctad Common Fund challenge and response

South African alternatives

Annual subscription (including postage):

\section{UK $£ 7$}

US \$20 (by accelerated surface mail)

Elsewhere $£ 9$

Orders may be sent to booksellers and newsagents, or to the Oxford University Press, Press Road, Neasden, London NW10 ODD (Tel. 01-450 8080) 
Comparative Studies in Society and History is a forum for presentation and discussion of new research into problems of change and stability that recur in human societies through time or in the contemporary world. It sets up a working alliance between specialists in all branches of the social sciences and humanities. Debate and review articles bring the general reader in touch with current findings and issues.

\section{NOTES FOR CONTRIBUTORS}

Contributions may be descriptive, analytical or theoretical. Any article not in itself comparative may be accepted if it lends itself to comment that will place it in comparative perspective. Correspondence with the editors prior to the submission of articles will help to enable them to obtain such comment or a companion study. Emphasis in comparative studies may be either on similarities or, if these are significant enough and call for some recasting of generalisations, on differences. All contributions and editorial correspondence should be sent to the Editors, Comparative Studies in Society and History, Department of History, University of Michigan, Ann Arbor Michigan 48109.

Two copies of each contribution, preferably accompanied by a stamped, addressed envelope, should be submitted. Both text and footnotes should be clearly typed with double spacing and wide margins; footnotes should appear on separate pages at the end of the article. Illustrations may be included by arrangement with the editors.

Contributors will receive 50 offprints. Any additional offprints must be ordered on receipt of the first proof.

ISI Tear Service, 325 Chestnut Street, Philadelphia, Pennsylvania 19106, U.S.A. is authorized to supply copies of separate articles for private use only.

Claims for missing issues will be considered only if made immediately upon receipt of the subsequent issue. 


\section{COMPARATIVE STUDIES IN SOCIETY AND HISTORY}

\section{Minorities and the Dominant Culture}

Bernard Wong A Comparative Study of the Assimilation of the Chinese in New York City and Lima, Peru

Mark A. Tessler The Identity of Religious Minorities in Non-secular States: Jews in Tunisia and Morocco and Arabs in Israel

Henry Rosenfeld The Class Situation of the Arab National Minority in Israel

\section{The Family in Social Context}

R. P. Neuman Working Class Birth Control in Wilhelmine Germany

P. Gibbon and C. Curtin The Stem Family in Ireland

Wanda Minge-Kalman The Industrial Revolution and the European Family: The Institutionalization of 'Childhood' as a Market for Family Labor

Alan Howard An Arsenal of Words: Social Science and its Victims A Review Article 